\title{
A Comparative Study of International Reports on COVID-19-Taking China Daily and the New York Times as Examples
}

\author{
Qingyun Han1, Pianpian Huang² \\ ${ }^{1}$ English Major, Zhejiang Yuexiu University, Shaoxing, China \\ ${ }^{2}$ Department of College English, Zhejiang Yuexiu University, Shaoxing, China \\ Email:37783302@qq.com
}

How to cite this paper: Han, Q.Y. and Huang, P.P. (2021) A Comparative Study of International Reports on COVID-19-Taking China Daily and the New York Times as Examples. Open Access Library Journal, 8: e7653.

https://doi.org/10.4236/oalib.1107653

Received: June 16, 2021

Accepted: September 26, 2021

Published: September 29, 2021

Copyright $\odot 2021$ by author(s) and Open Access Library Inc.

This work is licensed under the Creative Commons Attribution International License (CC BY 4.0).

http://creativecommons.org/licenses/by/4.0/

\begin{abstract}
With the changing of times and the rapid development of science and technology, the world is faced with global information. And the access to information becomes very important, especially in such special times as epidemic crisis. The media in every country are quickly gathering information to spread news internationally, which should be paid great attention to, for they are the focuses of the world, and the events in the news relate to the image of a country. However, every country has its own national condition, which naturally decides the differences existing in their media reports. China Daily and the New York Times are selected as research subjects, with chosen news ranging from February 2020 to May 2020. China Daily is the major media for foreign publicity in China, while the New York Times is also famous since the United States is the representative of the West. This paper explores international news on COVID-19 of the above two media to understand their differences and find out the reasons. In this paper, the content analysis method is adopted to extract part of international news for qualitative analysis. The ultimate goal of the comparative study is to improve China's external publicity capacity.
\end{abstract}

\section{Subject Areas \\ Journalism and Communication}

\section{Keywords}

China Daily, The New York Times, International News, Comparative Study

\section{Introduction}

With the constant updating of technology, the whole world has been connected 
by the Internet, and the earth has become a global village. Under such circumstance, politics, economy and culture of the whole world are all connected in different ways. Information globalization is accelerating. The news media play an indispensable role in the globalization of information. Lippmann pointed out in Public Opinion that people can only get to know things beyond their contact scope through various news supply organizations [1]. Therefore, in the dissemination of information, especially in the era of information globalization, every country should carefully treat contents of news. Allowing foreign information to flow freely without hindrance will have a huge impact on the domestic politics, economy and other aspects of social life [2]. Thus International news in the age of information globalization should be treated with caution.

But the development of global information is not always on the bright side. Western media always adopt the seemingly objective reporting method to prove the authority and credibility, and also use it as a tool to attack the news system of other countries [3]. The structural imbalance still exists in the current global information dissemination system. During the Cold War, the United States used its foreign broadcasting to divide the Soviet Union by beautifying its own image and uglifying the Soviet Union's image [4]. Years ago, in order to protect the political interests of their countries, western media carried out false propaganda regardless of the authenticity and objectivity of the news. This not only violates the social responsibility of the press, but also interferes in the internal affairs of other countries, causing a negative impact on world peace.

To study the international news about Corona virus disease-19 (COVID-19), we can understand the publicity strategies of different governments to deal with the epidemic, analyze the advantages and disadvantages from the effects of the strategies, and thus improve China's strategies. Secondly, the images of the countries can be clearly seen from the international news. Thirdly, we can reflect on the problems of external publicity from the analysis of the news materials and learn from more effective publicity methods.

This paper will adopt content analysis method. In terms of research subjects, China Daily and the New York Times are selected for comparative study, with the chosen news on COVID-19 ranging from February 2020 to May 2020. Through sampling analysis, this paper compares the two media's selection of news themes, headlines, words and pictures, and explores the reasons for these differences.

\section{The Two Newspapers' Different Features of International News on COVID-19}

\subsection{China Daily}

Firstly, there are mainly positive contents. The Chinese media mostly praise the contributions of health workers, oppose to discrimination against patients and call for common efforts to fight against the epidemic. For example, when COVID-19 spread across China around the 2020 Spring Festival, numerous medical workers have been reported risking their lives to stand up to adversity on the front lines 
in Wuhan. Under their influence, countless ordinary members of society have joined the efforts in any way they can. They have all been praised as "heroes in harm's way".

Secondly, journalists still strictly abide by the rules and regulations of reporting, follow the command of the CPC Central Committee, release articles carefully, stand together with the people and even guide the people's thoughts in a right way. So while the pursuit of time is an important factor for China Daily, it is far less important than the national image.

Thirdly, in terms of the achievements in fighting against the epidemic, those media have reported on the international praise for China, which not only inspires people's courage, but also highlights China's image in the international community. China's active prevention and control of the epidemic, the effective closure of cities, the establishment of the Vulcan Mountain and Raytheon Mountain Hospitals within only about 10 days, the national assistance to Wuhan and so on all reflect China's status as a responsible superpower.

\subsection{The New York Times}

The first striking feature of the New York Times is that it is highly engaged with its users, requiring them to $\log$ in and subscribe frequently. This feature will have different effects in such special times as epidemic times. News will be sent to the user's emails in time. The New York Times also uses other channels to inform users, which fully demonstrates the timely and diverse dissemination of news.

The New York Times' information on COVID-19 is largely critical of the negative. For example, the delivery of relief supplies is inadequate, patients are not actively treated, and the medical management system is not perfect. When reporting negative information, news will be accompanied by pictures closely related to the contents, which is visually shocking to people.

It is worth mentioning that the New York Times will publish some news in social network sites like Twitter to follow hot topics and attract users' attention and comments. One of the examples was the alarming misinformation to refer to the coronavirus as "China Virus". But the fact is while the virus originated in China, viral diseases don't have ethnic, racial or national characteristics. The New York Times' discrediting China's epidemic reports sometimes appeal to Chinese online users and news spread from Twitter to Chinese Sina Weibo.

\section{Comparison of the Two Newspapers' Contents of International News on COVID-19}

\subsection{Theme Selection}

The theme of news refers to the central idea and basic point of view of a news report. The theme of news plays a leading role, runs through the whole text, dominates the writing, and is the basis of news conception, material selection, and 
language expression.

The international news of China and the United States on COVID-19 also have different tendency to choose themes.

Among international news of China Daily, there are two articles entitled Books donated to COVID-19 patients in Wuhan, and Xi urges to be China-US action against COVID-19 in phone call with Trump. The contents of these two news articles are completely different. The first one is about the dedication of people to donate books, expressing the spirit of unity of Chinese people in the crisis and intending to encourage people. In the second article, China Daily is sending a signal to the world that China is willing to cooperate with the United States and other countries to fight against COVID-19. The common theme of these two articles is unity, which well reflects the ideological characteristics of Chinese journalists in their propaganda work.

Some of the international news in the New York Times has different themes with those of China Daily. For example, COVID-19 Threatens Global Safety Net and COVID-19, Confusion and Uncertainty. Both of these two articles have negative aspects. The first one is that COVID-19 threatens some developing countries and economically underdeveloped countries, but the US government prevents these countries from receiving aids. There is no doubt that the theme of this article is to expose the uncooperative behavior of the US government, which is a kind of irony. The second news article is to express the public's unease and worry about the development of the United States during the epidemic period. In this article, we can see the author's reflection and worry. Both of these articles show to the audience a negative theme, saying that the spread of COVID-19 has exposed problems in the government, and people are uneasy about their future lives.

In the author's opinion, the New York Times exposing national problems in international news and the straightforward expression are the advantages of American national newspapers, but the negative contents will not bring any benefits. China Daily, as a large foreign propaganda newspaper of China, always focuses on the country and society in its news, putting the benefits first and focusing on reassuring, encouraging and caring for the public, which will help push the epidemic work forward. The development of the news reports in China is conducive to the development of a people-oriented society and also the maintenance of the unity of the country and the people.

\subsection{Title Selection}

News title should summarize news contents in a high degree. More importantly, news titles should be short and concise to attract audiences since they are placed before the news content. The following is a comparison of the headlines of the two newspapers.

In the international news of China Daily, the language headlines are very concise, mostly describing news events or summarizing news contents. It is very 
important for readers to clearly express the specific contents of the events in a few words. For example: 'Mission: Impossible' sequels postponed over COVID-19 concerns. Some headlines, however, were likely to provoke a different reaction, like a news entitled Beijing lowers COVID-19 Restrictions. The use of the verb "lower" can be interpreted as a way to lower the restrictions because things are getting better. It can also be interpreted as a way to slightly criticize Beijing for lowering the restrictions, which is more emotional and less objective.

Headlines of the New York Times are vivid. For instance, How COVID-19 Is Making Millions of Americans Healthier? At the first sight, the main title uses interrogative rhetorical devices to arouse readers' interest and attract readers to go deep into the text. Take a second look at it, it links the virus and health together, which is very contradictory. But then the subtitle People Are Finally Cooking More makes an explanation so that readers can be clear right away. This kind of headline is fascinating, but if the reporter does not grasp the degree, it is easy to encounter the reader's aversion.

All in all, there is certain objectivity to both. The international news of the New York Times is relatively interesting and vivid, while there is room for improvement for China Daily in this aspect.

\subsection{Wording in the Context}

Journalistic professionalism requires that news reports should be objectively expressed and accurate, and concise language should be used to convey the facts. However, by its nature, journalism is subject to the control and interference of other systems of society. And any media has a subjective position, which is manifested in the system of news organizations and the attitudes of journalists towards events. The following is a comparative analysis of selected words and phrases in the texts of China Daily and New York Times so as to better understand the characteristics of the two media.

In the International News of China Daily, there is an article entitled All Confirmed Cases of COVID-19 in Vietnam Cured, Anti-epidemic Measures Strengthened. This report was written on February 26, 2020 when the virus was already spreading in most parts of the world, new cases appearing and then cured. In this article, Vietnam has reported no confirmed case after Feb. 13, while Vietnamese Prime Minister Nguyen Xuan Phuc has signed a directive to strengthen measures against the COVID-19 outbreak amid new concerning development across the world. The words in this article are properly used with a tone of objectivity. The only seemingly-not-so-serious word 'Concerning' is an objective description of concern.

In the international news of the New York Times, there is an article entitled How the World Missed COVID-19's Silent Spread. The content of this report is to reflect on people's negligence towards the virus and feel sorry for the loss of life. In the article, the sentence "earlier, aggressive action might have saved tens of thousands of lives" has two obvious adjectives, "earlier" and "aggressive", with 
strong emotions. One is a kind of accusation that the time of action is late. The other is the criticism of the poor effectiveness of anti-epidemic efforts. The reporter's emotions can be felt in the text, which is highly subjective.

To sum up, China Daily is more objective and positive, while the New York Times is more aggressive in criticizing wrong behaviors. As a silent weapon, the news language would express attitudes of the media accurately and vividly by properly displaying the adjectives with subjective colors in the objective expression.

\subsection{Picture Using}

News pictures will attract readers' strong attention because of their ability to restore the scene and the realistic sense of picture expression, which also makes them an indispensable part of news reports. News pictures can not only explain and illustrate the text, but also enhance the readability of the newspaper and arouse the emotional resonance of the readers. In the analysis of the international news reports of China Daily and New York Times, it will be analyzed from the nature of the pictures.

Among China Daily's International News, there is an article entitled Air Canada to Temporarily Lay off 16,500 Staff Due to COVID-19 Crisis. The article has a picture of two aircrafts at the airport. The content of the text is objective, closely related to the picture (see Figure 1). The pictures used in China Daily are monotonous and few in number.
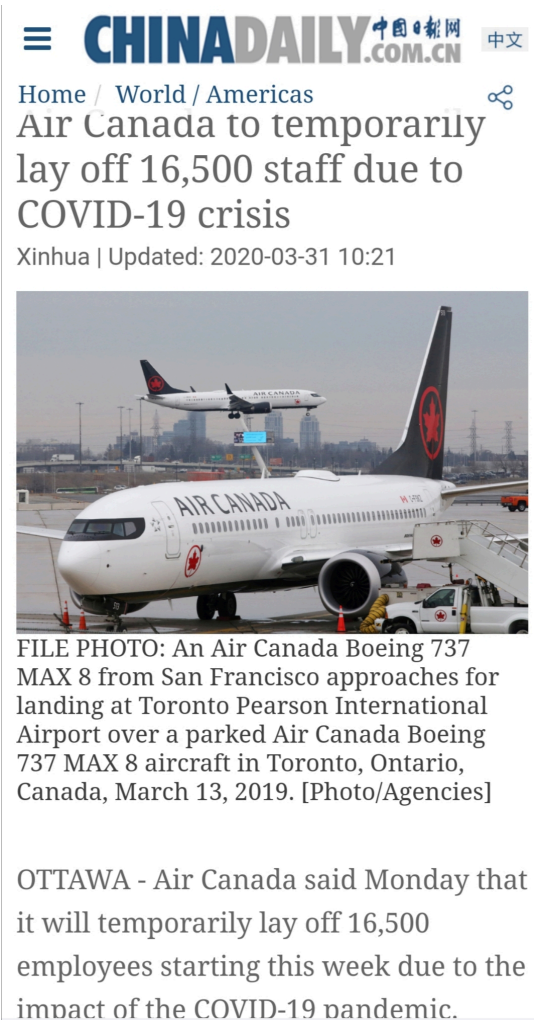

Figure 1. Picture used in China Daily's international news. 
The New York Times is full of pictures for international news. In the report, In Hunt for Virus Source, W.H.O. Let China Take Charge, there are 11 pictures directly showing the current situation on the streets of China, such as medical workers in protective suits and stranded people with luggage, vividly showing the confusion of people. The pictures, reflecting the dark side of Chinese anti-epidemic activities, do not actually reveal the reality. There is a pessimistic and opposed tendency in reporting this piece of news (see Figure 2). This article has several pages with those pictures, trying to show "China's surveillance system had failed to spot the outbreak, a failure that experts now say allowed its spread to accelerate", and accusing the World Health Organization of being too close to China.

From the above analysis, the New York Times has more perspectives and pictures than China Daily, but with its false contents, readers might be led to make mistakes and form wrong opinions, or even have improper behaviors.
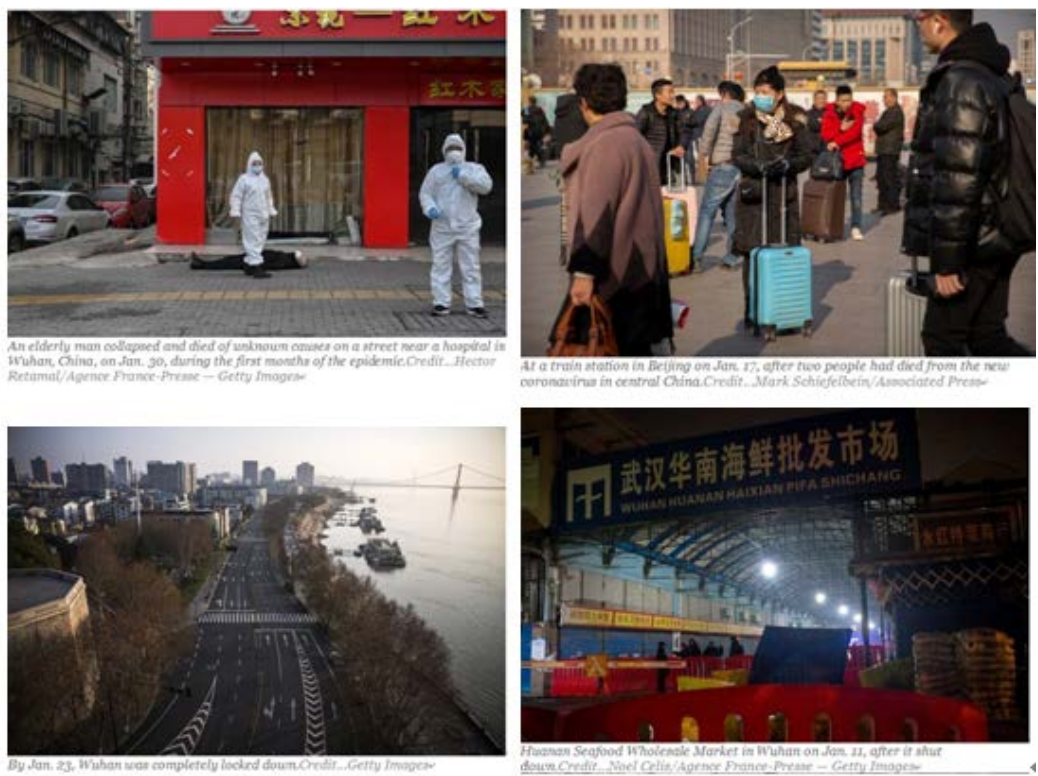
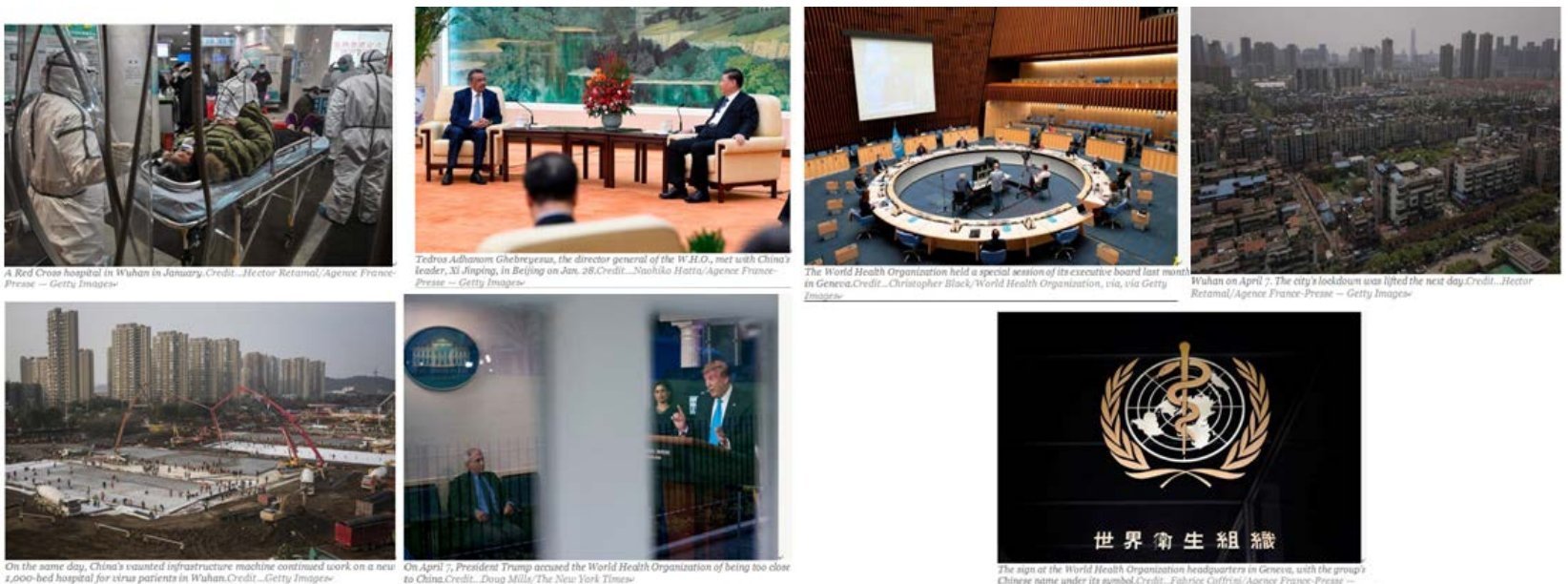

Figure 2. Pictures used in New York Times' international news. 


\section{The Reasons for the Differences between the Two Newspapers}

\subsection{Principles of News Reporting}

Journalistic professionalism also emphasizes that the media should assume the responsibility of reflecting public opinion, forming public opinion and safeguarding the public interest. Coombs said that crisis management is important because of advances in communication technologies that quickly bring crises to the attention of the public [5]. Media organizations, whether in the West or in China, are not only restricted by external factors such as politics, economy and society (including culture and public interests), but also restricted by internal logic and game rules in the organization's own field. Journalism arises from the interaction of media organizations with commercial interests, political systems, public interests and self-checks and balances.

The West has been pursuing the liberal economic model, which advocates free market theory and limited government theory, and calls for individual liberation and free development of people. Under this influence, various forces balance each other to promote the diversified development of the media. The news industry has also formed a relatively complete set of industry norms, and brought up a number of professional journalists with good quality and professional skills.

Journalistic professionalism in China has come under pressure from the state and politics, and is deeply imprinted with patriotism while reporting news and delivering information. The most basic social function of journalism has been relegated to the back burner. Compared with professional journalists in the West, Chinese journalists bear a heavier burden. They feel that most of them have families and the whole world in mind and will publish news in strict accordance with the system prescribed by the state.

\subsection{Value}

Value of news includes two aspects: one is the value of news fact itself; the other is the degree of attention and cognitive judgment of journalists to the value of news fact. The value of journalist is very important for Cheufele and Tewksbury said journalists can have an impact on both the volume and character of news messages about a particular issue [6]. The orientation of news' value is an important part of a social news communication system. It is restricted by the nature, constitution, development and change process of the news communication system of the group, and it is subordinate to the specific social system. At the same time, news themselves are a direct reflection of the orientation of the news' value of a certain society, which is different from the variety in politics, economy, culture and other aspects of the society, and which also results in the different orientation of the value of the news media.

$\mathrm{Li}$ and $\mathrm{Wu}$ has mentioned that Western news reports focus on revealing reports; Chinese news focuses on national image [7]. Media freedom in the United States is relatively strong, which is generated under the background of news 
commercialization, and it follows the concept of Commodity Exchange. Not all of the news on the New York Times website are free. After a certain number of stories are read, the website asks for a subscription to go on reading the news. So the values of American news media are consumer-centered. The value orientation of American news media in reporting international news, especially catastrophic topics like COVID-19, mainly includes such factors as abruptness, conspicuousness, abnormalism, importance and negative impact. China pays more attention to positive propaganda, which should lead people to unite as one and solve problems positively.

\subsection{Western Culture Hegemonism}

People are now living in an era of globalization, where different cultures interact and penetrate each other. However, the Western cultural hegemony represented by the United States has been spreading all over the world. The government uses the media to influence its people and exert a strong influence on the cultural ideology of the whole society. With the help of its economic advantages, the United States has formed a global information communication system, monopolizing nearly $90 \%$ of the world's news and information, and controlling $75 \%$ of the world's TV program production. Its network promotes American values and ideologies to the world in an all-round and all-time manner. As an American media, the New York Times may go against the wishes of the US government on domestic issues, but it will be highly consistent with the US government on external issues, slander other countries and make news in the news.

In the special period of international communication activities, the news media must step by step follow the national and international strategy. [8]

\section{The Strategies of Improving China's Foreign Publicity Ability}

\subsection{To Tell Good Chinese Stories}

Since the outbreak of COVID-19, General Secretary Xi Jinping has repeatedly stressed the need to tell well the stories of China's fighting against the epidemic. News should pay more attention to humanistic care, accurately grasp the emotional orientation, and build up values of audiences in the Internet era. In the new era, we should be more aware of the needs of the masses, be people-oriented, respect and pay attention to the reporting subjects, and care for people's living conditions and social rights and interests.

International news in the special period will attract more attention. It is necessary to innovate the means of reporting and communication, grasp the dominant position, take the initiative and gather positive strength in the field of domestic and international public opinion [9]. In the era of new media, not only traditional media have extensive propaganda power, omnimedia also have great influence. For example, the Fang Cabin Hospital in Wuhan was broadcast live, which attracted wide attention and made the information directly, quickly and 
vividly spread to the audience, showing the real China in front of the world.

Mainstream media should learn to make more use of foreign social media platforms, such as Twitter and Facebook, to fight against the discordant voices in the West, set a positive example on behalf of China, put national interests first, and cooperate with others to produce better international news.

\subsection{To Improve the Foreign Language Ability of the Media}

In today's era, the environment of public opinion, the pattern of the media and the mode of communication are all undergoing profound changes. To improve the media's ability of presenting news correctly and properly, language levels should also be paid more attention to, which is an important element to enhance the international discourse power. Therefore, it is required for international reporters to improve their foreign language levels. Taking higher levels of English tests such as CET6 and even TEM8 is a necessity.

\section{Conclusion}

This paper analyzes the differences between New York Times and China Daily in the international news on COVID-19, helps to understand the advantages and disadvantages of Chinese media in reporting international news, and aims to improve China's foreign publicity ability. The objective, fair and comprehensive coverage of international affairs will enable people to fully and timely grasp the international situation and help their governments make correct and wise decisions on issues concerning national interests. It is the fundamental task of the media to cultivate a group of people who are well informed of the international situation and have good judgments on international reporting. Only with such insightful media can the quality of a country's external communication be fundamentally improved. However, there are still rooms for improvement in the research. The study involves only dozens of pieces of international news, so the sample size is relatively small. If the study can be carried out in a larger scope, the results will be more convincing. Therefore, more researches need to be carried out in depth, and the sample scope should be wider.

\section{Conflicts of Interest}

The authors declare no conflicts of interest.

\section{References}

[1] Lippmann, W. (1989) Public Opinion. Huaxia Publishing House, Beijing.

[2] 程曼丽. 信息全球化时代的国际传播[J]. 国际新闻界, 2000(4): 17-21.

[3] 李惊雷. 西方媒体“病毒”伤害新闻报道的客观性原则——析某些媒体对我国非 典疫情的报道[J]. 新闻战线, 2003(10): 13-14.

[4] 孙有中. 国家形象的内涵及其功能[J]. 国际论坛, 2002, 15(3): 14-21.

[5] Coombs, W.T. (2010) Ongoing Crisis Communication: Planning, Managing and Responding. The IEEE Transactions on Professional Communication, 2, 174. 
[6] Cheufele, D.A., and Tewksbury, D. (2007) Framing, Agenda Setting, and Priming: The Evolution of Three Media Effects Models. Journal of Communication, 57, 9-20. https://doi.org/10.1111/j.0021-9916.2007.00326.x

[7] 李丹杰, 吴相如. 中西文化价值观念差异与新闻写作比较 [J]. 昆明大学学报, 2008, 19(3): 64-66+71.

[8] 黄河. 重大事件国际传播的人员部署战略研究一一以《纽约时报》西非疫情传播 活动为例[J]. 对外传播, 2017(3): 40-42.

[9] 崔士金鍂. 主流媒体如何做好突发公共卫生事件宣传报道一一以民日报新冠肺 炎疫情报道为例 [J]. 传媒, 2020, 22(5): 12-16. 